\title{
GAMBARAN PEMILIHAN KONTRASEPSI VASEKTOMI PADA PASANGAN USIA SUBUR DI KECAMATAN BOGOR SELATAN TAHUN 2019
}

\author{
Sulha1, Fenti Dewi Pertiwi² \\ ${ }^{1}$ Kesehatan Ibu dan Anak, Program Studi Kesehatan, Fakultas Ilmu Kesehatan Universitas Ibn Khaldun Bogor \\ Email : sulha217@gmail.com \\ 2Program Studi Kesehatan Masyarakat, Fakultas Ilmu Kesehatan Universitas Ibn Khaldun Bogor. \\ Email : fenti.dewi.pertiwi@gmail.com
}

\begin{abstract}
Abstrak
Mayoritas penduduk Indonesia menganut budaya patriahal yang memperkuat ego pada pria, menganggap program keluarga berencana tanggung jawab istri, Partisipasi masyarakat dalam program keluarga berencana masih didominasi wanita dari pada pria. Pendekatan studi ini adalah kualitatif dengan desain RAP (Rapid Assisment Procedur) menggunakan wawancara mendalam dan observasi. Sampel informan berjumlah 19 orang terdiri dari 11 informan kunci, 4 informan akseptor KB vasektomi dan 4 informan akseptor non vasektomi. Hasil penelitian menyimpulkan bahwa sebagian besar informan memilih vasektomi pada usia 30 tahun, berstatus pekerja, Jumlah anak 2-6 orang, pendidikan yang pernah ditempuh Sekolah Dasar. Sebagian besar mendapat dukungan istri untuk ikut vasektomi, pengetahuan terhadap kontrasepsi cukup baik, jarak ketempat pelayanan dapat ditempuh, dan sumber informasi yang didapat sebagian besar dari PLKB.
\end{abstract}

Kata Kunci : PUS, Vasektomi, Kontrasepsi.

\section{PENDAHULUAN}

Indonesia merupakan negara dengan Jumlah Penduduk terbesar ke 4 (empat) didunia setelah Cina, India dan Amerika Serikat (Profil kesehatan Indonesia, 2017). Data tersebut memberikan peringatan bahwa penduduk dunia khususnya Indonesia masih relatif tinggi, Untuk Menekan Jumlah Laju Pertumbuhan Penduduk, maka pemerintah menggalakkan upaya program Keluarga Berencana (KB), Upaya akselerasi pembangunan Kependudukan dan Keluarga Berencana (KKB) dengan memperhatikan RPJMN dan Renstra BKKBN tahun 20102014, Program Keluarga Berencana memiliki makna yang strategis, komprehensif dan fundamental dalam mewujudkan Masyarakat Indonesia yang Sehat dan Sejahtera (PUSDATIN, 2013). Hal yang memprihatinkan dari partisipasi pria sebagai akseptor KB adalah angka keikutsertaannya yang rendah, data SDKI (2002-2003) menunjukan angka partisipasi pria ber-KB secara nasional hanya sekitar 4,4\% kondom (0,4\%), vasektomi $(0,4 \%)$, pantang berkala $(1,6 \%)$, dan senggama terputus sekitar $(1,5 \%)$. Jumlah peserta KB pria diindonesia tahun 2015, sebanyak (1,00\%) Kondom, (6,21\%) Implan, (3,23\%) MOW, (0,27\%) vasektomi (Rencana Aksi Nasional Pelayanan Keluarga Berencana, 2015). Hal ini disebabkan karena Mayoritas penduduk Indonesia menganut budaya patriarkhi yang semakin memperkuat ego dalam diri pria yang menganggap bahwa KB menjadi tanggung jawab istri, dan diperkuat data Kemenkes RI menunjukkan partisipasi masyarakat dalam ber-KB masih didominasi oleh kaum wanita dari pada kaum pria, dan hanya sebagian kecil pria berpartisipasi menjadi 
akseptor vasektomi, dimana pria yang melakukan vasektomi dianggap tidak maskulin menjadi penyebab utama kekhawatiran para pria untuk berpartisispasi dalam upaya program KB khususnya vasektomi (Indrayani, 2014).

Jumlah penduduk Jawa Barat pada tahun 2015 diperkirakan sebanyak 46,709 juta jiwa yang menjadikaan Jawa Barat sebagai salah satu provinsi terbesar jumlah penduduknya di Indonesia. Jika di lihat dari kabupaten/Kota ternyata Kota Bogor memiliki jumlah penduduk terbanyak setelah kabupaten kuningan yaitu sebesar 1.047 juta jiwa. selain itu bogor sendiri menjadi salah satu daerah penyangga ibu kota sehingga menyumbang hampir sepertiga dari total penduduk jawa barat atau sebanyak 30,8\% populasi (PUSDATIN, 2013).

\section{METODE}

Penelitian ini dilakukan dengan pendekatan kualitatif desain $R A P$. Penelitian dilakukan pada bulan Januari sampai Maret 2019 diwilayah Kecamatan Bogor Selatan. Pemilihan lokasi penelitian disebabkan karena di Kecamatan ini masih rendahnya pemilihan alat kontrasepsi vasektomi dikalangan Pasangan Usia Subur, dibandingkan dengan kecamatan lainnya yang berada di Kota Bogor.

Populasi dalam penelitian ini adalah seluruh PUS (Pasangan Usia Subur) yang ada di Kecamatan Bogor Selatan yang berjumlah 9.295 Pasangan. Sampel berdasarkan kriteria purposive sampling dibagi menjadi informan dan informan kunci. Informan kunci yang digunakan dalam penelitian ini, yaitu 1 orang Koordinator Lapangan, 2 orang petugas PLKB dan 8 orang istri dari masing-masing akseptor.

Kriteria Informan dibagi menjadi 2, yaitu informan akseptor KB Vasektomi yang tinggal di kecamatan bogor selatan, merupakan penduduk tetap/asli berjumlah 8 orang. Jenis informan kedua merupakan suami KB Non vasektomi denga total sample sebanyak 19 orang.

Instrumen yang digunakan adalah pedoman wawancara mendalam dengan pertanyaan terdiri dari variabel karakteristik, umur, Pekerjaan, Jumlah Anak Hidup, Pendidikan, Dukungan istri, Jarak ketempat pelayanan, Sumber informasi, Pengetahuan, dan Sikap. Instrumen ini dilakukan uji coba satu kali pada populasi dan sampel yang berbeda untuk mengukur tingkat pemahaman dari pertanyaan dalam pedoman wawancara.

Analisis data kualitatif dengan validitas dan reliabilitas data. Validitas yang digunakan yaitu trianggulasi sumber, trianggulasi data dan triangulasi metode. Trianggulasi sumber dengan mengkroscek jawaban informan akseptor dengan istri, Koordinator Lapangan dan Petugas KB lapangan (PLKB). Trianggulasi data dengan menganalisis dokumen data dari DPPKB untuk mengkroscek populasi sampel informan. Kemudian data dianalisis lalu membuat matriks.

\section{HASIL}

a. Usia

Berdasarkan hasil wawancara mendalam dengan informan inti yang memilih vasektomi sebagian besar memiliki usia diatas 30 tahun, namun satu dari empat informan lainnya memilih vasektomi diusia 28 sedangkan sebagian besar informan inti yang tidak memilih vasektomi berusia diatas 35 tahun.

“Usia... saat ini lima puluh delapan tahun,waktu di MOP itu... dua delapan emm..." (IN-01) 
"Yah usia bapak sekarang lima puluh Sembilan lahir tahun enam puluh, pas di MOP saat itu usiaa kepala empat kalau ga salah, kepala empat atau kepala tiga waktu itu yah karena anak-anak udah tujuh terus istri sakit-sakitan yaudah bapak langsung yang turun hehe... untuk ikut KB" (IN-02)

"Usiaa... sekarang empat puluh tujuh taun kelahiran tujuh puluh dua" (IN-07)

\section{b. Pekerjaan}

Informan inti dalam penelitian sebagian besar berstatus sebagai pekerja, baik informan inti yang memilih vasektomi maupun informan yang tidak memilih vasektomi.

"Mmm... yah, Pekerjaan saya ya gitu aja, bikin sandal, jualan yah paling gituh ajah..." (IN04)

"Pekerjaan awal pertama tahun Sembilan puluh itu ikut di desa genteng tahun dua ribu satu sampe dua ribu dua itu di dinas kebersihan kabupaten bogor, selain itu juga pernah jadi tukang gali kabel PLN pasang listrik dan sekarang kerja di kelurahan cikaret sudah cukup" (IN-07)

\section{c. Jumlah Anak hidup}

Jumlah Anak hidup dari informan inti yang memilih vasektomi paling sedikit 2 orang dan paling banyak 6 orang. Sedangkan informan inti yang memilih vasektomi memiliki jumlah anak sebanyak 4 orang.

"Jumlah anak dua, satu perempuan satu lagi yang udah menikah perempuan, yang laki belum tapi sudah bekerja" (IN-01)

"Anak saya enem waktu itu udah enem. Perempuannya tiga yang lakinya tiga jadi enem semuanya" (IN-03)

"Emem yang udah menikah disebutin aja ya, perempuan tiga laki satu emmm yang satu udah punya keluarga yang tiga lagi... udah kerja yang paling bontot masih sekolah" (IK06)

\section{d. Pendidikan}

Berdasarkan hasi wawancara yang dilakukan 3 (tiga) dari 4 (empat) informan inti yang memilih vasektomi menyatakan bahwa pendidikan terakhir yang pernah ditempuh adalah Sekolah Dasar (SD), sedangkan 3 (tiga) dari 4 (empat) informan inti lainnya memiliki pendidikan terakhir Sekolah Menengah Atas (SMA).

"Yah pendidikan waktu itu Cuma sampe SMP, karena orang tua meninnggal ita bapakjadi ikut kakak jadi serbasalah. Akhirnya sampe SMP kelas tiga berenti langsung kabur dari... pasar minggu ke Jakarta, ketanjung periuk ama om ikut kerja, SMP ngga lulus sama kesd sayangnya Cuma sampe kelas tiga itu aja, ngga ikut di ujian ngga apa karena kabur dari rumah, karena ikut kaka serbasalah gimana yah, ama suaminya bertengkar aja, yaudah saya ngalah gitu hehehe..." (IN-02)

\section{e. Dukunga Istri}

Berdasarkan hasil wawancara mendalam sebagian besar istri dari informan yang memilih vasektomi menyatakan mendukung suami dalam memilih kontrasepsi vasektomi. Dengan 
dukungan yang cukup beragam mulai dari membantu dalam proses perawatan, membantu menyaran karena istri tidak cocok menggunakan $\mathrm{KB}$, membantu mengusulkan untuk ikut vektomi.

"Waktu pertama bapak bilang abis di vasektomi, saya sempet kaget kalau bapak bener ikut KB hehe... yaudah dari situ saya ikut ngurusin, sama membantu ngerawat sampe sembuh gituh...saya seneng kalau bapak sampe ikut kb, jadai saya ngga harus ikut kb, yang bikin badan gemuk huu... " (IK-01)

"Pertama kali waktu bapak mau di MOP, saya sangat mendukung keputusan bapak sebab selama ini saya sakit-sakitan sampe badan saya kurus gara-gara ikut KB" (IK- 02)

\section{f. Jarak ketempat Pelayanan}

Berdasarkan hasil wawancara mendalam sebagian besar informan mengatakan bahwa jarak menuju ke tempat pelayanan kesehatan tidak terlalu jauh, bahkan dapat di jangkau dengan jalan kaki.

“Eh... kalau ke tepat pelayanan mah kaya puskesmas gitu ya ngga, ngga terlalu jauh tinggal jalan aja, eh... itu yang didepan puskesmas mulyaharja paling lima menitan sampe" (IN-01)

\section{g. Sumber Informasi}

Sebagian besar informan inti mendapat informasi terkait KB yaitu dari petugas PLKB.

“Dari... PLKB pak engkos aja sih paling kalau di kasih tau masalah KB mah" (IN- 04)

\section{h. Pengetahuan}

Informan non vasektomi lebih memahami vasektomi dari pada informan yang memilih vasesektomi, karena dilihat dari jawaban yang diungkapakan oleh informan tentang vasektomi adalah pengikatan saluran sperma, pemutusan saluran sperma seumur hidup.

"Apa yah hehe... kalau misalkan si itu kan yang di putus itu kan, itu kan katanya itu seumur hidupkan ngga bakalan punya anak gitu" (IN-06)

"Setau saya apa kaya dii hehehe diiket ga tau juga saya ya bu ya. jadi operasi kecil hanya untuk pengikatan saluran sperma dalam pem laki-laki, tapikan saya ngga tau ini juga apa sipatnya permanen apa sementara ini apa bisa du buka lagi apa permanen saya ngga tau" (IN-08)

\section{i. Sikap}

Sedangkan terkait sikap suami dalam pemilihan vasektomi masih sangat kurang, akrena dilihat dari alasan yang di utarakan informan yang memilih vasektomi mengatakan alasan memilih vasektomi karena istri tidak cocok menggunakan kb sehingga menyebabkan sering sakit, lupa jadwal ulang, dan karena bujukan orang lain.

"Ya karena saya kan tau sendiri bu sakit- sakitan aja jadi bapaknya dikal yang ngalah, takut kebanyakan anak udah cukup makanya enam, tujuh yang idup jadi semua, jadi enam karena takut sendiri lah penghasilannya sekarang ini kan tau sendiri hehehe jamannya sulit nyiar duit, ngga kaya dulu" (IN-02)

"Alesaannya gini kata pak lurah gini ayo ikut sama bapak KB entar geh kenimatan mah 
sama, saya ngga mikir-mikir lagi yaudah saya ikut, kebetulan kan istri saya ngga cocok pake $K B$, tapi saya sekarang nyesel karena itu nikmat yang paling gede itu di putus bayangin aja. jalan keluarnya mending istrinya yang di KB entah di suntik lah, atau pake kondomlah silahkan tapi di putus jangan. (IN-03)

\section{PEMBAHASAN}

Sebagian besar informan inti memilih vasektomi pada usia lebih dari 30 tahun hal ini sejalan dengan penelitian yang dilakukan oleh Fitri, dkk (2013) yang menyatakan bahwa semakin tua umur responden maka akan semakin tinggi angka pemakaian kontrasepsi pria, yang berarti bahwa responden yang berumur lebih dari 35 tahun mempunyai kecenderungan lebih besar untuk memilih kontrasepsi vasektomi.

Secara umum informan inti berstatus sebagai pekerja, dengan pekerjaan yang dilakukan diantaranya wirausaha, petugas kecamatan, dan petugas kelurahan. Hal ini sejalan dengan penelitian Patonah (2016) yang menyatakan bahwa suami yang bekerja cenderung sibuk dengan apa yang dikerjakaannya sehingga membuat mereka minim informasi dalam hal kesehatan, selain itu mereka beranggapan bahwa kontrasepsi hanya dikhususkan untuk perempuan dan untuk seorang laki-laki kontrasepsi adalah hal yang tabu.

Berdasarkan hasil wawancara mendalam Jumlah Anak Lahir Hidup pada informan inti yang memilih vasektomi memiliki anak paling sedikit 2 orang dan anak terbanyak yang dimiliki yaitu sebanyak 6 orang. Hal ini sejalan dengan penelitian yang dilakukan oleh Wulandari, dkk (2015) yang menyatakan bahwa responden yang memiliki anak lebih dari 2 cenderung memilih menggunakan metode MKJP.

Berdasarkan hasil wawancara mendalam dapat diketahui sebagian besar pendidikan yang pernah ditempuh oleh informan inti yang tidak memilih vasektomi adalah Sekolah Menengah Pertama (SMA). Hal ini diperkuat oleh hasil penelitian yang dilakukan oleh Putri (2015) menyatakan bahwa tingkat pendidikan seseorang belum tentu dapat mempengaruhi cara penerimaan informasi yang didapatnya, semakin tinggi tingkat pendidikan belum tentu semakin cepat atau mudah dalam penerimaan ilmu atau informasi.

Berdasarkan hasil wawancara mendalam yang dilakukan, 5 (lima) dari 8 (delapan) informan kunci menyatakan mendukung suami untuk mengikuti vasektomi. Dukungan yang dikatakan informan kunci karena alasan sakit-sakitan atau tidak cocok menggunakan alat kontrasepai, lupa jadwal ulangan, dan sebagian besar informan mengatakan karena penambahan berat badan. Dukungan yang diberikan meliputi membantu suami dalam pemilihan kontrasepsi, ikut merawat saat pemulihan.

Hal ini sejalan dengan penilitian yag dilakaukan oleh Wahyuni, dkk (2013). menyatakan bahwa akseptor KB pria yang memiliki dukungan keluarga yang tinggi, cenderung ikut berpartisipasi dalam vasektomi dari pada akseptor KB pria yang dukungan keluarganya rendah.

Informan inti yang memilih vasektomi dan tidak memilih vasektomi memiliki jarak rumah yang dekat dengan pelayanan kesehatan. oleh karena itu, jarak memiliki hubungan untuk informan datang ke tempat pelayanan kesehatan. hal ini juga diperkuat dengan hasil penelitian yang dilakukan oleh Fienalia Rainy Alus (2012) yang menyatakan bahwa ada hubungan yang signifikan antara jarak ketempat pelayanan kontrasepsi dengan penggunaan 
Metode Kontrasepsi Jangka Panjang (MKJP).

Sumber Informasi yang didapat 4 (empat) dari 8 (delapan) informan menyatakan bahwa informasi yang didapatnya yaitu dari Pak Lurah, Keluarga, dan Petugas PLKB . Hal ini sejalan dengan hasil penelitian yang dilakukan Penelitian yang dilakuakn Putri (2015) menyatakan bahwa sumber informasi yang didapat melalui teman, petugas kesehatan, serta media cetak atau media masa sangat berpengaruh terhadap pemilihan kontrasepsi vasektomi, karena suami akan mendapatkan informasi secara langsung sehingga akan mudah terpengaruh dari informasi yang mereka dapatkan.

Sedangkan 4 (empat) 8 (delapan) informan inti lainnya tidak mengetahui tentang definisi vasektomi, sehingga pengetahuan informan dikatakan masih kurang karena dilihat dari hasil penjabaran yang dikemukanan masih belum maksimal dan belum sesuai dengan teori yang mendefinisikan kontrasepsi vasektomi sebagai suatau metode operasi kecil pada saluran vasedeferen, atau tindakan pengikatan, penyumbatan saluran mani pria pada waktu akan bersenggama. Hal ini sejalan dengan penelitian yang dilakukan Arianto (2018) yang menyatakan bahwa masih banyak responden yang tidak mengetahui metode kontrasepsi Vasektomi, dikarenakan tingkat pendidikan yang rendah berpengaruh terhadap penggunaan alat kontrasepsi Vasektomi.

Sedangkan 6 (enam) dari 8 (delapan) informan inti menyatakan yang seharusnya menggunakan KB adalah istri karena memang sudah KB adalah urusan perempuan, selain itu informan juga menyatakan bahwa apabila laki-laki yang ikut KB terkesan aneh. Hal ini diperkuat oleh hasil penelitian Ariyanto (2018) didapat bahwa masih adanya responden yang bersikap ragu-ragu yang disebabkan karena adanya ketidak percayaan terhadap sesuatu hal, serta nggapan bahwa alat kontrasepsi adalah urusan wanita, sedangkan untuk vasektomi merupakan hal yang tabu bagi pria.

\section{KESIMPULAN}

Sebagian besar informan inti memilih untuk ikut vasektomi pada usia lebih dari 30 tahun, Pekerjaan merupakan suatu kendala untuk laki-laki dalam memilih vasektomi, karena informan inti yang tidak memilih vasektomi berstatus sebagai pekerja. Jumlah Anak yang dimiliki informan inti yang memilih vasektomi sebanyak dua sampai enam orang. Informan inti yang memilih vasektomi yaitu Sekolah Dasar (SD). Satu dari empat informan inti yang ikut vasektomi tidak mendapat dukungan dari istri dan bahkan melarangnya. Waktu yang dibutuhkan untuk ketempat pelayanan kesehatan dari semua informan mengatakan tidak terlalu lama sehingga dapat di jangkau dengan berjalan kaki. PLKB merupakan sumber informasi yang paling banyak dipilih dalam mencari informasi. Pengetahuan informan inti mengenai kontrasepsi vasektomi dapat dikatakan masih kurang Sebagian besar informan merespon baik terhadap penggunaan alat kontrasepsi vasektomi. 


\section{DAFTAR PUSTAKA}

Arianto. Nurfitriani. 2018. Gambaran Pengetahuan Dan Sikap Pria Produktif Terhadap Metode Kontrasepsi Vasektomi. Program Studi D3 Keperawatan, STIKes Baiturrahim Jambi. Jurnal Akademika Baiturrahman. Vol. 7 No. 1, Maret 2018.

Bakri, I., Sari, M. M., \& Pertiwi, F. D. (2019). Hubungan Dukungan Suami Dengan Pemberian Asi Eksklusif Di Wilayah Kerja Puskesmas Sempur Kota Bogor Tahun 2018. Promotor, 2(1), 27. https://doi.org/10.32832/pro.v2i1.1786

D. T. Agina, F. D. Pertiwi and I. Avianty, "Faktor - Faktor Yang Berhubungan Dengan Perilaku Penggunaan Vapor di Kalangan Siswa Sekolah Menengah Kejuruan Bina Sejahtera 2 Kota Bogor," PROMOTOR Jurnal Mahasiswa Kesehatan Masyarakat, vol. 2, no. 2, pp. 101-111, 2 April 2019.

DPPKB Kota Bogor. 2018. Rencana Kerja Perangkat Daerah

Dinas Pengendalian Penduduk dan Keluarga Berencana 2017. Bogor : DPKB Kota Bogor.

Dirjen Bina Gizi dan KIA. 2013. Rencana Aksi Nasional Pelayanan Keluarga Berencana 20142015. Jakarta : Kementrian Kesehatan RI.

(Di Kecamatan Tejakula Kabupaten Buleleng. Program Study Megister Keluarga Pascasarjana UNS. Jurnal Magister Kedokteran Keluarga. Vol. 1, No 1, 2013 (hal 80-91) http://jurnal.pasca.uns.ac.id.

Fitri, Miratul. Wantouy, Benny. Tendean, Lidya. 2013. Pengaruh Vasektomi Terhadap Fungsi

Seksual Pria. Kandidat Skripsi. Fakultas Kedokteran, Universitas Sam Ramtulangi. Jurnal e-Biomedik (eBM), Volume 1, Nomor 1, Maret 2013, hlm. 496-502.

Fartaeni, F., Pertiwi, F. D., \& Avianty, I. (2018). Hubungan Pengetahuan, Sikap dan Dukungan Suami Terhadap Pemberian ASI Eksklusif Di Desa Pabuaran Kecamatan Gunung Sindur. Healty Jurnal Kesehatan Masyarakat, 6(1). https://doi.org/10.32832/hearty.v6i1.1255

Fitrianingtyas, Pertiwi, dan Rachmania, W. Faktor-Faktor yang Berhubungan dengan Kejadian Kurang Energi Kronis (KEK) pada Ibu Hamil di Puskesmas Warung Jambu Kota Bogor. HEARTY Jurnal Kesehatan Masyarakat. 2018;6(2):1-8.

KEMENKES RI. 2017. Profil kesehatan Indonesia 2017. Jakarta : Pusat Data dan Informasi KEMENKES RI 2017.

Kusnadi NR, Rachmania W, Pertiwi FD. Faktor-Faktor Yang Berhubungan Dengan Pemilihan Metode Kontrasepsi Suntik Pada Peserta KB Aktif Di Kelurahan Mekarwangi Kecamatan Tanah Sareal Kota Bogor Tahun 2019. Promotor. 2019;2(5):402-9.

Pertiwi, F. D., Hariansyah, M., \& Prasetya, E. P. (2019). FAKTOR RISIKO STUNTING PADA BALITA DIKELURAHAN MULYAHARJA TAHUN 2019. PROMOTOR, 2(5). https://doi.org/10.32832/pro.v2i5.2531

Pertiwi, F. D., Rahman, R. M., \& Lestari, D. W. (2018). Pemberdayaan masyarakat melalui bidang literasi di Desawaru Jaya. Jurnal ABDI DOSEN: Jurnal Pengabdian Pada Masyarakat, 2(2), 129-137. https://doi.org/10.32832/abdidos.v2i2.170

Pertiwi FD, Isnawati. gambaran pengetahuan dan sikap ibu hamil tentang tanda bahaya kehamilan di Puskesmas Caringin Kabupaten Bogor tahun 2015. HEARTY Jurnal Kesehatan Masyarakat Vol.5 No.1 2017.

Pertiwi, F. D., \& Farihah, N. (2017). Hubungan Lingkungan Dengan Kejadian Infeksi Saluran Pernafasan Akut (Ispa) Pada Balita Di Wilayah Kerja Uptd Puskesmas Semplak Tahun 
2016. Hearty, 5(2). https://doi.org/10.32832/hearty.v5i2.1056

PUSDATIN. 2013. Situasi dan Analisis Keluarga Berencana. Jakarta Selatan : KEMENKES RI Pusat data Dan Informasi 2013.

Patonah, Siti. S, Atik. Imanu, Paulus. 2014. Gambaran Sikap Pasangan Usia Subur (Suami) Dalam Pengunaan Alat Kontrasepsi Keluarga Berencana (Vasektomi) Di Desa Panjunan Kecamatan Kalitidu Kabupaten Bojonegoro. Asuhan Keperawatan. Vol. No. 2, Maret Agustus 2016.

Rachmania, W., Kurniawan, D., \& Pertiwi, F. D. (2019). Gambaran Tingkat Pengetahuan Tentang Implan Pada Wanita Usia Subur Di Kelurahan Katulampa Kecamatan Bogor Timur Kota Bogor. Hearty, 7(1), 1-11. https://doi.org/10.32832/hearty.v7i1.2304

Siti HS, Fenti DP, Ichayuen A. Gambaran Pengetahuan Orangtua, Dukungan Keluarga, Dan Status Imunisasi Terhadap Kejadian Difteri Pada Balita Di Wilayah Puskesmas Cileungsi Kabupaten Bogor Tahun 2018. Jurnal Mahasiswa Kesehatan Masyarakat. 2019.

Wulandari, Yunita. Dkk. (2015). Faktor-faktor yang mempengaruhi penggunaan Metode lontrasepsi jnagkan Panjang (MKJP) pada Pasangan Usia Subur di kabupaten sambas. Jurnal. Fakultas Ilmu Kesehatan Masyarakat Universita Muhamadiayah Pontianak.

Wahyuni, Ni Putu. Suryani, Nunuk. K, Murdani Pancasria. 20013. Hubungan Pengetahuan Dan Sikap Akseptor Kb Pria Tentang Vasektomi Serta Dukungan Keluarga Dengan Partisipasi Pria Dalam Vasektomi 